v.13, n.6

Vitória-ES, Nov.-Dec. 2016

p. $210-230$ ISSN 1808-2386

DOI: http://dx.doi.org/10.15728/bbr.2016.13.6.3

\title{
The Role of Public Institutions for Innovation Support in Brazil
}

\author{
Cláudia Brito Silva Cirani ${ }^{\dagger}$ \\ Nove de Julho University - UNINOVE \\ Carlos Mamori Kono $^{\Omega}$ \\ Nove de Julho University - UNINOVE \\ André Moraes dos Santos ${ }^{¥}$ \\ Nove de Julho University - UNINOVE \\ Adalberto Ramos Cassia ${ }^{ \pm}$ \\ Nove de Julho University - UNINOVE
}

\begin{abstract}
The aim of this study was to present a brief description of the main public instruments for innovation support in Brazil. We also show a preliminary assessment of the use of these instruments in innovative companies. We conducted a two-step analysis. In the first part we conducted a quantitative descriptive analysis of historical series about resources allocation available by FINEP. In the second part we performed a qualitative in-depth analysis of six companies that used the financial benefits offered by FINEP and BNDES to support innovative projects. The responses of the interviews were used to identify the perception of the attractiveness of public instruments for innovation support and possible limitations to their use, while other information was used to present the main public instruments for innovation stimulus in Brazil. The results showed that the investigated companies are interested in using the instruments; however, they face difficulties for their adoption, due to excessive bureaucracy, high costs of innovation, and legal insecurity.
\end{abstract}

Keywords: Tools for innovation support. FINEP. BNDES. Enterprises. Brazil.

Received on 05/08/2015; Reviewed on 09/02/2015; Accepted on 09/29/2015; Divulgued on 11/01/2016.

*Author for correspondence:

$\dagger$. Doctor in Applied Economy. Link: Nove de Julho University

- UNINOVE.

Address: Francisco Matarazzo

Avenue, 612, Prédio C, $2^{\circ}$ floor,

Água Branca - São Paulo (SP)

- Brazil. Cep. 05001-100.

E-mail:

claudiabscirani@gmail.com
$\Omega$ Doctoral student in Administration.

Link: Nove de Julho University - UNINOVE.

Address: Francisco Matarazzo Avenue, 612, Prédio C, $2^{\circ}$ floor, Água Branca - São Paulo (SP) Brazil. Cep. 05001-100.

E-mail:

carloskono@sistec.net.br
$\Omega$ Doctoral student in Administration.

Link: Nove de Julho University - UNINOVE.

Address: Francisco

Matarazzo Avenue, 612, Prédio C, $2^{\circ}$ floor, Água Branca - São Paulo (SP) Brazil. Cep. 05001-100.

E-mail: amsantos@univali.br
$\Omega$ Doctoral student in Administration.

Link: Nove de Julho University - UNINOVE. Address: Francisco Matarazzo Avenue, 612, Prédio $\mathrm{C}, 2^{\circ}$ floor, Água Branca - São Paulo (SP) Brazil. Cep. 05001-100. E-mail:

adalb2002@gmail.com

Note from the Editor: This paper was accepted by Bruno Felix. 


\section{INTRODUCTION}

nnovation, in the context of this study, concerns the technological innovation resulting from the systematic and routine work of research \& development (R\&D) and the instrument of competitiveness among enterprises to ensure profitability and generate growth and development to the country. Innovation has always been a priority for major corporations and, recently, it has become a central issue for smaller companies,

which have become global participants (TIDD; BESSAN; PAVITT, 2008).

Defined as the introduction to the market of a product (goods or service) technologically new or substantially improved or the deployment of a technologically new or improved production process (REZENDE; TAFNER, 2005), technological innovation was considered important by Porter (1990) in that innovation and improvement in methods and technology are central elements for the competitiveness of a country. Therefore, one of the biggest challenges for companies is to identify the sources of innovation and define how to fetch or use them (STAL, 2007), participating in institutional arrangements that involve alliances, partnerships, consortia and networks of strategic cooperation with universities, research institutions or other companies, including competitors.

Investment in innovations based on new technologies generates financial risks, high degree of uncertainty about the return on investment and the difficult decision to choose between purchasing (diffusion) or performing internal R\&D. Such options are not necessarily substitutive, but complementary, since the purchase of technology also allows to generate innovation and develop skills for the enterprise to identify, assimilate and explore knowledge. However, to keep R\&D with the increasing technological complexity, high costs and risks, pressure for results, lead to the alternative of cooperative arrangements to leverage resources, share risks, define standards, and conduct research. The consensus that this activity cannot be attributed only to the private sector, justifies the involvement of agents of the National Innovation System, defined by Stal (2007) as a network of public and private institutions that interact to promote the scientific and technological development of a country.

Technological innovation should be considered a key point for developing countries to become competitive, being necessary to create an environment to stimulate innovation (PORTER, 1993). Posner (1961) describes the technology gap theory as a consequence of research activity and entrepreneurship, new goods are produced and the innovating country enjoys a monopoly until the other countries learn to produce these goods: in the meantime they have to import them. Fagerberg (1987) confirm that there exists a close correlation 
between the level of economic development, measured as GDP per capita, and the level of technological development, measured through R\&D or patent statistics. Also show that the importance of innovation for economic growth has increased lately, while at the same time imitation, (or diffusion) has become more demanding (FAGERBERG; VERSPAGEN, 2002).

Developing countries policies to foster innovation need to take into account several obstacles, such as technology gap, competition and misalignment between some of their instruments and the inefficacy of procedures for economic subvention that restrict funds to productive and innovative projects in the technological area considered critical for the country's development (CASSIOLATO; LASTRES, 2010).

Thus, it is crucial that governments introduce policies to encourage and support entrepreneurial innovation. In Brazil, public policies supporting technological innovation do not always converge with scientific policy and only after the market opening in 1990, the private sector began to invest in $\mathrm{R} \& \mathrm{D}$, which leads to persisting notorious lack of technological innovation (STAL et al., 2006).

In this context, the decade of 2000, represents a huge change in Brazil's technological policy to support innovation by creating a diverse set of tools designed to encourage innovation in companies. These policies comprised the creation of instruments for more effective cooperation between the public and private spheres; the effort of integrating technological policies; the creation of broader federal government strategies aimed at industrial development; and significant increase of the amount of public funds to support business innovation activities. The significant change in this decade, therefore, meant the reorientation of science and technology policy (S\&T) for innovation; the breakup with the whole trajectory of research support that favored the evolution of basic and academic science; and the increased focus on the company, market and productive sector for innovation and competitiveness of the economy (BASTOS, 2012).

The contribution of financial resources and legal-institutional arrangements for the support of innovation from the Federal Government between 2000-2010 reached more than US\$ 21.36 billion in current values, representing an average of US\$ 1.96 billion annually. Until 2004, initiatives within the Ministry of Science, Technology and Innovation (MCTI) and the Brazilian Innovation Agency [FINEP] concerning the non-refundable instrument predominated and from 2005, the refundable financing of the Banco Nacional de Desenvolvimento Social (National Bank for Social Development [BNDES] was introduced (BASTOS, 2012). In 2003, the launch of the guidelines of the Industrial Policy and Foreign 
Trade (PITCE) jointed horizontal lines of action focusing on innovation and technological development, strategic options, and future activities, relying on instruments for innovation support provided by FINEP and BNDES, benefited by Law $n^{\circ} 10,973 / 2004$ and Law $n^{\circ}$ $11,196 / 2005$.

However, the issue arises when you question the effectiveness to implement the instruments for innovation support, which depends on factors that are directly related to public agencies (providers) and companies (users). It means that funding agencies must set priorities and strategic actions to achieve desired goals, while enterprises must design their own strategies, clearer in their concepts and innovation projects (CGEE; ANPEI, 2009). This implies, for both parties, relevant changes in structures, skills and organizational culture. In this work, the operation of the main instruments for innovation support in Brazil and the experience of businesses in using these instruments are questioned.

The aim of this study was then to present a brief description of the main public instruments for innovation stimulus in Brazil, as well as submit a preliminary assessment of the use of these instruments in innovative companies. We hope that this work contributes to the improvement of implementation and use of programs and instruments to promote innovation in Brazil.

This work is divided into five sections, including this introduction. The second section presents a literature review on how the State should act through an Industrial Policy to promote the productive activity in the national territory and then, it presents a brief history of the Industrial Policy of Brazil. The third section shows briefly the methodology adopted. The fourth section provides a descriptive analysis of the operationalization of the instruments to support innovation provided by FINEP, as well as the modalities of support offered by FINEP and BNDES. Next, we present the results of the use of these instruments, based on interviews with innovative companies. The fifth section brings the final considerations of the work.

\section{THE ROLE OF THE STATE IN INNOVATION SUPPORT}

\subsection{INDUSTRIAL POLICY}

Historically, the State has always played an important role in the industrialization processes of European countries acting as an agent of industrial development, however, questions arise when discussing the effectiveness of the private system in allocating scarce economic resources to the needs of the society at certain times. According to Ferraz, Paula \& Kupfer (2002), the strategy and the intervention mode of the State must be consistent with the 
stage of development of a country, always having as a reference, the panorama in the international environment.

Therefore, an Industrial Policy (IP) is essential to "keep the leading position or outdo competitors from other nations" (FERRAZ; PAULA; KUPFER, 2002, p. 564). These authors discuss the national policy under three aspects. In the orthodox view, also called neoclassical, the market allocates resources efficiently, making the IP useless and sometimes even undesirable. Its intervention would make sense only as a regulator, in an essentially corrective posture. On the developmental vision, the State must act as a corrective and active element, with legitimacy to promote and sustain development. The State development leads the market, takes initiative and mobilizes instruments.

In the evolutionary vision, the State examines the IP related to the search for competence for innovation and highlights the relations among the market structure, business strategy, and technical progress, emphasizing the constant interaction of the company with the market. Competition is a dynamic process, the market is the locus of the strategic interactions and the rivalry between the companies that invest in skills acquisition to gain position on the market. In this context, innovations are the engine of capitalism development (SCHUMPETER, 1997). Market failures, then, constitute the growth strength and structural change of capitalism and the State plays the role of amplifying the intensity of the selection process, creating institutions that facilitate the process of generating and disseminating new technologies. This innovation policy encompasses the IP and technological policy and State intervention takes place both on the demand side and the technological supply.

These concepts are reinforced by Suzigan \& Furtado (2006) that conceptualize an active and comprehensive IP, directed to the economic and institutional environment as a whole, which disregards the assumption of equilibrium (combination of the strategic role of innovation in the economic development with the theoretical formalizations of Evolutionary Economics). The concept proposes a co-evolution of technologies, companies and industry structures and institutions in a broad sense, having innovation as a driving force. These authors suggest a most appropriate approach to the formulation and implementation of an IP as a strategy of development to be compatible with the macroeconomic policy, establish goals, articulate instruments and norms. Thus, the establishment of IP is vital in an industrial strategy driven by innovation and guided by technological and structural changes of companies and industries. This should be the result of collaborative efforts of the public and private sectors (JOHNSON, 1982; apud SUZIGAN; FURTADO, 2006). 
The strategy and intervention mode of the State should be consistent with the stage of development of a country. The PITCE guidelines, in Brazil, consolidated the centerlines for the innovation policy, prescribing incentives for innovation and scientific and technological research in the productive environment. The set of instruments to encourage innovation in the federal scope includes repayable and non-repayable financing and tax incentives.

\subsection{THE INDUSTRIAL POLICY IN BRAZIL-PITCE}

The analysis of learning and innovation processes in the Brazilian industry is developed by Fleury \& Fleury (1997) and Ferraz, Paula \& Kupfer (2002), considering three periods.

The period of 1945-1980 corresponds to the implementation of the Brazilian industrial park, with typical demands of the economic development process and with ventures of private, multinational and state-owned enterprises. The governmental action for industrialization aimed at replacing imported goods through protectionism policies; direct and indirect subsidies; high taxation; and little interest in technological capability, not considered strategic, as technology could be purchased in foreign markets.

The period of 1980-1990, considered a transition, had its start from a strong movement of resistance to any organizational change due to the threat of technological unemployment (automation), exacerbated by the uncertainty of the IPs and macroeconomic instability.

The period after 1990, at the beginning of President Collor Government, shows characteristics of transition to an industrial organization context marked by the parameters of competitiveness. During this period, the forfeiture of the currency from the market zeroes the demand, generating idleness and the need to rebuild business relations with customers and suppliers. In addition, the market is no longer protected, changing some basic premises that guided companies, and the most important premise is the "discovery of the importance of the market" (FERRAZ; PAULA; KUPFER, 2002, p. 133), which was perceived when enterprises found themselves threatened by competition with foreign companies. In this phase, the technological fragility is clear, with technology excellence restricted only to conventional production practices. This period marks the beginning of the pressures for changes in search of greater competitiveness for several reasons: exporting effort started by leading national enterprises; export becomes a part of the strategy of parent companies; domestic customers automakers and state-owned companies inserted in the production chains; the domestic market, that is, national companies operating in non-export segments; and national companies in traditional sectors without external competition. 
Innovation was neglected until the 1980s due to the policy of import substitution, which explains the gap that was established between universities (research development) and enterprises (buying external technologies). Reducing this gap led the Federal and State Governments to implement specific programs to support innovation. The Brazilian Government's concern with the scientific and technological development only became clear in the late 1960s, from the implementation of specific plans and programs that were restructured or that created governmental agencies to encourage, support, and guide the R\&D activities performed at universities, research centers and companies. In 1967, FINEP was created and, two years later, its main financial instrument - the National Fund for Scientific and Technological Development (FNDCT) was implemented.

FINEP, currently named as the Brazilian Innovation Agency, is the primary agency to support technological innovation at a federal level and its scope encompasses the basic research performed at universities, applied research conducted at research institutes and innovation activities in companies. The BNDES, in turn, is the ideal agency for substantial and comprehensive financial support for installation or reinstallation of factories, modernization and technological development or purchase of equipment aiming to ensure competitiveness (STAL, 2007).

In 2003, seeking to overcome the anti-IP bias that prevailed for a long time, the Federal Government launched guidelines for industrial policy and foreign trade, based on three pillars: 1) horizontal lines of action focusing on innovation and technological development, insertion in the external market, industrial modernization, expansion of productive capacity and production scale; 2) strategic options including semiconductors, software, capital goods, pharmaceuticals and medicines; 3) activities with a future potential, such as biotechnology, nanotechnology, biomass and renewables.

Technological innovation is the central pillar of industrial policy and foreign trade that consolidated the centerlines of the innovation policy, with the approval of the Law $n^{\circ}$ $10,973 / 2004$ and the proposal for the Law $n^{\circ} 11,196 / 2005$, which prescribe incentives for innovation and scientific and technological research in the productive environment, aimed at creating a favorable environment to increase the commitment of companies to the development of innovative projects in order to generate new products and processes and to establish a high level of partnerships between enterprises, universities, and scientific and technological institutes strengthening and stimulating the innovation process (PEREIRA; KUGLIANSKAS, 2005). 


\section{METHODOLOGY}

The analyses of this work are presented in three steps. The first is a brief description of the operationalization of the instruments provided by FINEP for innovation support, given its greater tradition in financing innovation in Brazil, with emphasis on volume of resources allocated by area and modality. Descriptive analyses allow to analyze the behavior of variables over time using quantitative data (CONTANDRIOPOULOS et al., 1997).

The period of this analysis referred to the historical series from 2007 to May 2013, because this range covers the longest series of information made available by FINEP (2013), when this work was carried out. Once the data were organized, the tables and figures were developed to show the behavior of the aspects investigated over time. The data representation through tables and figures becomes an attractive and expressive form of presentation, because it facilitates the visualization all data (MARCONI; LAKATOS, 2002).

In the second phase, the instruments for innovation support, based on data survey from the website of the financing agencies seeking to introduce the modalities of support offered by FINEP and BNDES.

The third phase was anchored on interviews conducted in 2013 with six innovative companies, intentionally selected, since they aim to use the financial support of FINEP and BNDES to support innovative projects. The six companies were experienced in FINEP and BNDES grants and agreed to accomplish a deep interview with the researchers. The qualitative nature of this research phase was concerned in gathering 'deep' information more than obtain generalizations in relation to the population from which the cases were drawn. The responses from the interviews were used as primary sources, while other information obtained from the website of these companies were used as secondary sources, in order to evaluate their mission, commitment to innovation, and relationship with the funding agencies.

The respondents are engaged in relevant functions in the area of product development, $\mathrm{R} \& \mathrm{D}$ or with direct involvement with the management of innovation in the companies. In addition, the selected companies have very peculiar characteristics about the way they manage their financial resources to support their innovative activities. The companies were referenced in the results presented below as E1, E2, E3, E4, E5 and E6 and their respondents effectively engaged in innovation management were identified as R1, R2, R3, R4, R5 and R6, respectively. The respondents' perspective can bring intrinsic limitation to the study, due to the subjectivity of the respondents. However, the work is very reliant on the reading that the authors had during the interviews, therefore, we cannot assign to the respondents the 
viewpoints presented here, except when expressly noted.

Evidently, in view of the scope of work, companies do not comprise a representative sample for statistical purposes, since the purpose of the interviews was to perform an initial assessment of the conditions for the use of public instruments to stimulate innovation, for example, the profile of the companies benefited, the level of knowledge of the instruments and their use by the company; problem identification for the use of the instruments; the companies' perception about the dissemination of the modalities of public support for innovation; among other issues. Therefore, generalizations cannot be adopted, except for the specific implications associated with companies here investigated.

After collecting the data, the information obtained from the interviews was prepared for the analysis, interpretation and production of the research report (CRESWELL, 1998). The analysis of the interviews was carried out through the technique of content analysis, defined by Bardin (2000) in order to obtain the actual meaning of the responses obtained.

\section{RESULTS}

\subsection{RESULTS OF THE USE OF INSTRUMENTS FOR INNOVATION SUPPORT - FINEP}

Financial incentives are mechanisms of innovation policy of Governments directed mostly to industrial sectors to specific projects or partnerships among companies, universities and research institutes, empowering the Government to define clearly its strategy of technological development and socioeconomic impacts, providing repayable and nonrepayable funding lines (AVELLAR, 2010).

Tax incentives, in turn, allow the decisions of where and how investments in R\&D are conducted by companies, which support the agents to better assess which project will be more successful. It is considered an instrument of support more transparent and flexible, since it can attend different objectives, types of enterprises and industrial sectors simultaneously. This mechanism does not have a credit limit ceiling, thus, it is directly related to the decisionmaking process and the effective cost of companies.

In Brazil, in the period of 2006-2008, the Research of Technological Innovation (PINTEC, 2008) by the Brazilian Institute of Geography and Statistics [IBGE] showed that the companies used funding sources for their own R\&D (76\%) and third parties (24\%). In addition, Government support for innovative activities of industrial enterprises and services included economic subsidy (311) and tax incentives - R\&D (492) and Law $\mathrm{n}^{\circ}$ 8248/1991 (748) -, while the funding programs for Research, Development and Innovation (RD\&I) 
projects included partnership with universities (383), without partnership (581); purchase of machinery and equipment (5,559), and other programs (2,981) (IBGE, 2010).

Below are more details of the frame of instruments for innovation support, based on data survey from FINEP, agency with greater tradition and culture in the analysis of innovation projects in Brazil. Table 1 shows the distribution of the companies that used the benefits of FINEP per area between 2007 and May 2003, which is rather concentrated in Multi-area. This area received $74.41 \%$ of the total resources US\$ 3.65 billion in the period of analysis. However, as defined by FINEP, the Multi-area category is very wide encompassing all that did not fit in other areas. Therefore, the support for infrastructure stands out for its high amount of resources allocated between 2007 and May 2003. This area accounted for $12.71 \%$, totaling US\$ 624.1 million.

Table 1 - Amount of Investments of FINEP per Area - 2007 (US\$) - May/2013

\begin{tabular}{lcc}
\hline Area benefited & Total & \% \\
\hline Multi-area & $3,653,256,840$ & 74.41 \\
Infra-structure & $624,119,282$ & 12.71 \\
Others & $241,326,806$ & 4.92 \\
ICT & $76,232,105$ & 1.55 \\
Pappe (micro and small business) & $59,829,060$ & 1.22 \\
Oil & $48,824,947$ & 0.99 \\
Health & $46,642,415$ & 0.95 \\
Energy & $29,280,394$ & 0.60 \\
National defense and public security & $22,097,449$ & 0.45 \\
Social development & $19,037,635$ & 0.39 \\
Technological centers & $17,147,863$ & 0.35 \\
Agriculture \& Livestock & $14,487,180$ & 0.30 \\
Water supply & $14,150,893$ & 0.29 \\
Biotechnology & $11,986,356$ & 0.24 \\
Incubators & $6,486,206$ & 0.13 \\
Art \& Culture & $5,187,997$ & 0.11 \\
Education & $4,637,581$ & 0.09 \\
Nanotechnology & $4,456,048$ & 0.09 \\
Aeronautics & $3,429,078$ & 0.07 \\
Water courses & $2,941,487$ & 0.06 \\
Researcher at enterprises & $1,609,393$ & 0.03 \\
Water resources & 906,753 & 0.02 \\
Pharmaceutical & 682,206 & 0.01 \\
Total & 656,795 & 0.01 \\
\hline Source: Research & $\mathbf{1 0 0 . 0 0}$ \\
\hline
\end{tabular}

Source: Research data.

As shown in Table 1, FINEP provided US\$ 4.9 billion in resources. Such resources were distributed among 1,319 benefited companies, among which, $20 \%$ received $80 \%$ of the total resources available in the studied period (Figure 1). 


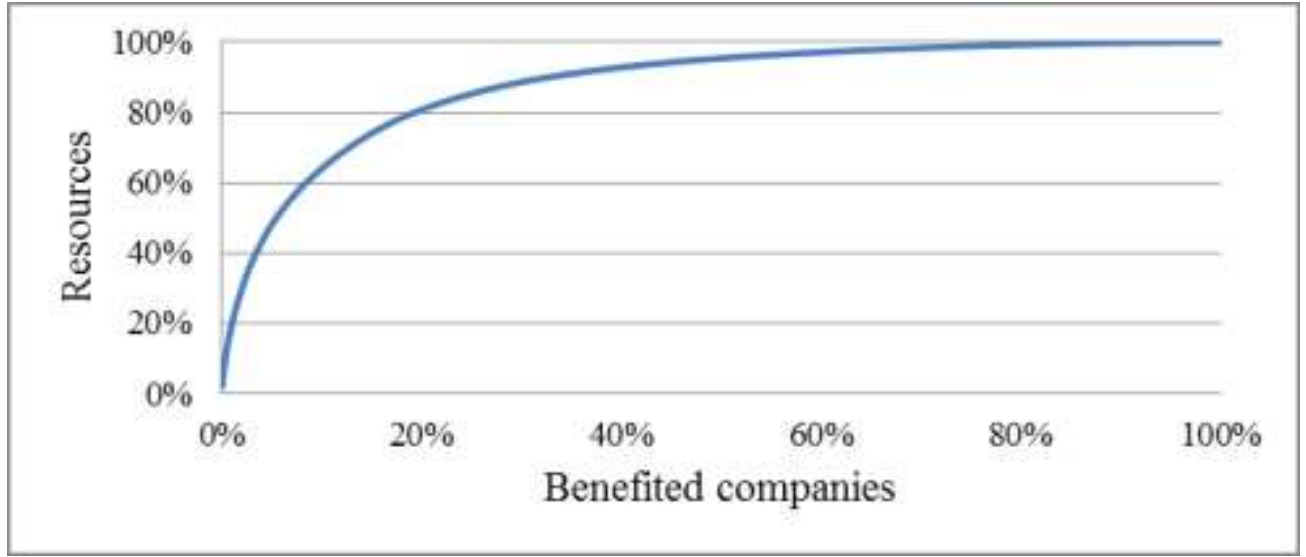

Figure 1 - Allocation of FINEP resources to benefited companies (proponents) - 2007 to May/2013

Source: research data.

Table 2 shows that the resources for the repayable financing line of FINEP were significantly higher, except for the first two years (2007-2008). Regarding the last year, it is crucial to remember that the presentation of the collected data considers only until May 2013, which explains the relatively low values when compared to previous years.

Table 2 - Amounts Invested by FINEP per Modality - 2007 (US\$)- May/2013

\begin{tabular}{crr}
\hline & \multicolumn{1}{c}{ Modality } \\
\cline { 2 - 3 } Year & Non- Repayble & Repayble \\
\hline 2007 & $186,806,944$ & $160,560,406$ \\
2008 & $378,865,486$ & $249,892,442$ \\
2009 & $282,435,593$ & $625,143,093$ \\
2010 & $407,670,721$ & $487,331,721$ \\
2011 & $178,610,047$ & $661,617,498$ \\
2012 & $350,005,230$ & $696,465,075$ \\
2013 & $43,674,183$ & $207,948,241$ \\
\hline
\end{tabular}

Source: Research data.

\subsection{INSTRUMENTS FOR INNOVATION SUPPORT}

\subsubsection{Non-repayable}

Within the scope of FINEP, taxes were created and procedures were established for the link with FNDCT, whose resources, non-repayable modality, are allocated for cooperative projects related to companies committed to innovation. A similar approach was adopted by BNDES, with the creation and operationalization of FUNTEC in 2006 with resources from the bank's annual profits (BASTOS, 2012). Table 3 shows the non-repayable instruments, supported by the funding agencies. 


\begin{tabular}{|l|l|}
\hline $\begin{array}{l}\text { FINEP } \\
\text { Economic } \\
\text { subsidy }\end{array}$ & $\begin{array}{l}\text { Use of resources directly to the companies to share the costs and risks inherent to the } \\
\text { research, development, and innovation activities. }\end{array}$ \\
\hline $\begin{array}{l}\text { FINEP PAPPE } \\
\text { Economic } \\
\text { subsidy }\end{array}$ & $\begin{array}{l}\text { Program to support a micro and small technology business, in partnership with foundations } \\
\text { to support research, Sebrae or federations of the industries. Partners operate it in a } \\
\text { decentralized way. }\end{array}$ \\
\hline $\begin{array}{l}\text { FINEP PRIME } \\
\text { First enterprise }\end{array}$ & $\begin{array}{l}\text { For emerging enterprises of high-aggregated value aiming to consolidate its initial phase, to } \\
\text { cover for human resources and services of specialized consultancy. }\end{array}$ \\
\hline $\begin{array}{l}\text { BNDES- } \\
\text { FUNTEC }\end{array}$ & $\begin{array}{l}\text { Technological and innovation development of strategic interest for the country, according to } \\
\text { public programs and policies. }\end{array}$ \\
\hline $\begin{array}{l}\text { Technological } \\
\text { fund }\end{array}$ &
\end{tabular}

Table3 - Non-repayable instruments for innovation support from FINEP and BNDES

Source: Research data.

\subsubsection{Repayable}

The pioneering of repayable public financing started with FINEP with the Support Program for the Technological Development of National Industry, followed by the ProInnovation Program, and finally by the Inova Brazil, retaining the guidelines but readjusting to the guidelines of the Productive Development Policy (PDP). BNDES has repayable financing sectorial programs that contemplate $R \& D$ and innovation through specific subprograms. The two federal agencies grant funding with reduced charges to support technological innovation in enterprises. The difference between the cost of financing for the borrower and the "effective" rate is covered by FINEP through the transfer of budgetary resources, while BNDES covers the difference through profits in other operations. These lines are presented in Table 4.

\begin{tabular}{|l|l|}
\hline FINEP- Inova Brasil & $\begin{array}{l}\text { Support to strategic investment plans for research, development and innovation } \\
\text { projects. It assists enterprises of distinct sizes. }\end{array}$ \\
\hline FINEP -Zero interest & Innovation projects of micro and small businesses with regional partners. \\
\hline $\begin{array}{l}\text { BNDES - } \\
\text { Innovative capital }\end{array}$ & $\begin{array}{l}\text { By acquisition of real estate assets in publicly traded enterprises. The focus is the } \\
\text { enterprise, not the project. Centered in the company strategy and innovation. }\end{array}$ \\
\hline $\begin{array}{l}\text { BNDES - } \\
\text { Technological Innovation }\end{array}$ & $\begin{array}{l}\text { Financing research, development and radical innovation projects that represent } \\
\text { technological risk and market opportunity. }\end{array}$ \\
\hline BNDES -BNDES card & To invest in products and processes of goods, inputs and services. \\
\hline BNDES - Automatic & $\begin{array}{l}\text { Implantation, expansion and modernization projects of ventures, including } \\
\text { investment in P,D \& I. }\end{array}$ \\
\hline BNDES - Credit Limit & Rotated credit for the enterprise or economic groups already clients. \\
\hline BNDES - Sectorial & $\begin{array}{l}\text { Pro-R\&G; Pro-pharmaceutical; Pro-software; Pro-plastic; Pro-aeronautics; Pro- } \\
\text { engineering; PROTVD, BNDES PSI; BNDES Qualification. }\end{array}$ \\
\hline $\begin{array}{l}\text { Joint action } \\
\text { FINEP-BNDES }\end{array}$ & $\begin{array}{l}\text { PAISS (sugar-ethanol sector); Inova Energy (energy sector); Inova Petro (suppliers } \\
\text { of the productive chain of oil and natural gas); and Inova Health (innovation in the } \\
\text { health sector). }\end{array}$ \\
\hline
\end{tabular}

Table 4 - Repayable instruments for innovation support from FINEP and BNDES

Source: Research data. 
There are great similarities in the design of the credit lines and their modalities of operation, thus, both institutions tend to attract the same potential customers. The total repayable funding between 2000-2010 amounted US\$ 4.27 billion, 58\% from FINEP and $42 \%$ from BNDES (BASTOS, 2012).

\subsubsection{Tax incentives}

The tax incentives were established during the economic opening in Brazil in the 90sand underwent successive revisions and improvements. The arrangement of tax incentives is the subject of criticism, by focusing only on medium and large-size companies (subject to real profits scheme, not the non-presumed method used by small businesses), and due to legal uncertainty (definitions of expenses likely to be deducted by base for calculating the real profit of companies). The types of tax incentives are presented in Table 5.

\begin{tabular}{|l|l|}
\hline PDTA and PDTI & $\begin{array}{l}\text { Program for the Industrial and Agricultural Technological Development (replaced } \\
\text { by Lei do Bem, regulated by Decree 5,798/2006). }\end{array}$ \\
\hline $\begin{array}{l}\text { Lei da Informática } \\
\left(\text { Law } \mathrm{n}^{\circ} 10,176 / 2001\right)\end{array}$ & $\begin{array}{l}\text { It grants tax incentives to companies that produce specific equipment. Reduction of } \\
\text { IPI, as compensation for the investment in the R\&D of products. }\end{array}$ \\
\hline $\begin{array}{l}\text { Lei do Bem } \\
\left.\text { (Law } \mathrm{n}^{\circ} 11,196 / 2005\right)\end{array}$ & $\begin{array}{l}\text { It expands and simplifies the use of tax incentives by the enterprises, in } \\
\text { compensation for the increase in the industrial technological park in Brazil, and } \\
\text { consequently the improvement of national products. }\end{array}$ \\
\hline $\begin{array}{l}\text { Lei do MEC } \\
\left(\text { Law } \mathrm{n}^{\mathbf{0}} 11,487 / 2007\right)\end{array}$ & $\begin{array}{l}\text { It allows enterprises to use tax incentives to finance projects conducted by } \\
\text { universities and research centers. }\end{array}$ \\
\hline
\end{tabular}

Table 5 - Tax incentives

Source: Research data.

The new tax incentives for innovation, imposed by Law $n^{\circ} 11,196 / 2005$, represented a significant expansion of the benefits granted to enterprises by Law $n^{\circ} 8,661 / 1993$ and had as attractiveness its automatic application, that is, companies are exempted from presenting a previous project to start benefiting from the incentives. In 2006, the first year of validity of the new tax incentives, 130 companies were benefited, $56 \%$ of them located in the southeastern region and $40 \%$ in the southern region, concentrated in the mechanical, transport, metallurgical and chemical sectors (57\%). Although Law n ${ }^{\circ} 11,196 / 2005$ has been effective for a short time, figures from 2006 and 2007 seem to confirm the assessment that the new tax incentives have proven rather attractive for companies operating under the regime of real profit, and that they are likely to spark the interest of other companies.

\subsection{RESULTS OF INTERVIEWS}

As already mentioned, in this work, the selection process of interviews prioritized companies recognized for their innovative results, which will be referenced by E1, E2, E3, E4, E5 and E6, and professionals belonging to the area of development or involved with 
innovation management were interviewed that will be identified by R1, R2, R3, R4, R5 and R6, respectively.

Firstly, characteristics of the companies selected are presented. Then, there is the initial assessment that these companies make of the conditions of using the public instruments for innovation support, with a focus on the sense of attractiveness of such instruments and any restrictions to their use.

E1 is a company based in the city of São Paulo and with its main activity in the manufacturing of computers and automation. The company invested US\$ 32.47 million in 2012, from which, US\$28.2 million in R\&D. Mostly, the investment in R\&D was directed to the development of products in the segments of banking and business automation (CVM, 2013).

E1 placed a request for two patents in the automation segment: a patent on a technology that allows the user to start the transaction of withdrawing money in automated teller machines from their mobile device, and another patent on a device that reduces the physical contact of the customer with the equipment, increasing the security of users' data.

In addition, E1 won three awards for excellence in its activities: the first recognizing its capacity of service delivery in the agency environment; the second highlighting the expertise in developing solutions focused on customers' processes; and the third certifying the capacity to offer security solutions, monitoring and combating fraud against its customers.

This company used the BNDES financing line in 2011 for a total of US\$21.79 million and FINEP in 2009 for a total of US\$ 33.3 million. The company's estimates suggest an average of $30 \%$ of public resources in the financing of innovation projects of the company in the last three years. R1 mentioned that the company has full knowledge of public instruments, as well as legal knowledge required in its organizational structure, relying on a specialized team for the elaboration and submission of innovation projects.

R1 stated that the instruments of public support to business innovation meet the need of the company that seeks exactly the resource volume provided for in the public notice. R1 also reported that the problems encountered in the adoption of the instruments are minimal, associated with accounting, and operational and administrative procedures required to obtain the resources.

According to R1, sector associations, such as the Brazilian Association of Electrical and Electronics Industry [ABINEE], are the main instruments for the dissemination of the 
mechanisms of public support for innovation, as well as consulting firms that specialize in managing innovation. R1 reports, "there is a lot more dissemination by indirect channels, and information about the modalities can be increased if there is more dissemination by direct channel from the financing agencies and government in general".

Since 2008, E2 has operated in the IT sector of services, developing solutions for new media with a focus on interactivity. Its main activity is to develop applications for digital TV and its main customer is the SKY - satellite television. E2 also develops self-service applicative and management for the content of indoor media. The small company is formed by three partners with headquarters in the city of Santos, São Paulo State, Brazil.

Although the company is incubated in the Incubator Center of Technological Companies of the University of São Paulo [CIETEC-USP], when E2 planned to deploy an innovation, many difficulties arose in terms of legal aspects, equipment acquisition, company restructuring, personnel training, hiring external consultants, among others. Therefore, the company provided legal support to meet the requirements of the funding agencies.

E2 had the support of FINEP through the First Innovator Company - PRIME for US\$ 51,282 and for National Service of Industrial Learning/Social Service for Industry [SENAI/SESI] of Innovation for US\$ 170,940. This company reported that it was relatively easy to obtain resources. This can be explained by the fact that the company was incubated at CIETEC-USP, once being part of an incubator linked to USP is essential for the viability of the business, because in addition to help in managing the company, the aggregated credibility when the company requests access to public resources for innovation is critical.

E3 operates in the electronics and manufacturing industry, with its headquarters in Brusque, Santa Catarina State, Brazil. It has an industrial park of 53,000 $\mathrm{m}^{2}$ and employs 1,000 people and, in 2012, it registered gross sales of US\$154.2 million. The company produces gas stoves, barbecue grills and electric grills, kitchen hoods, electric ovens, bicycles, and machinery for civil construction.

E3 used the spontaneous demand program of FINEP in the public notice released in 2007, aiming at the improvement and expansion of its productive park. The project ran from 2009 to 2012 and the amount was US\$ 5.5 million. The company learned of the FINEP financing instrument by means of external consultancy in 2007. However, the company is unaware of the process of forwarding forms to apply for the resources. The whole process was conducted by the external consultancy, which charged a fee on the amount of the funds 
approved. At the company, the responsible for the engineering and production sectors interacted with the external consultant for the elaboration of the project. R3 stated that, currently, through visits of representatives of Euvaldo Lodi Institute of Santa Catarina (IEL/SC), he learned of the existence of financing lines of the Inova Brazil Program. R3 mentioned, "the programs are not well disseminated and the enterprises learn about them through external consultants".

R3 stated that when the enterprise used the resource of FINEP, between 2009-2012, the support was essential for the expansion and improvement of productivity, and lower interest rates were important to reduce costs with the investment. This resulted in improvements in quality and productivity, necessary to face external competition. Currently, the company considers the submission of a proposal for funding by FINEP or BNDES for process and product improvement. However, the project is not formalized yet.

E4 is a small company founded in 2004, but already recognized as an innovative company, which received the ANPEI Stamp for innovative company due to its commitment to innovation. The company operates in the electricity sector, and in 2012, it employed 28 people. According to R4, the company's activities were based on "from the beginning in innovation (R\&D), with the orientation of FINEP at the beginning for the formation of the company in partnership with an outside investor, developing technologies that do not exist in the Brazilian industrial scope".

R4 reports the excessive bureaucracy of the funding agencies, for example, the excessive requirement of technical and functional details; the time-consuming analysis and approval processes; and the final figures released derisory. For R4, "companies seek competitiveness, innovate with their own resources and the government claims that it is supporting innovation”. R4 stressed that they have no invention or innovation registered because it is in the developmental stage, with a forecast to start production within two years. Therefore, the company is being structured to use the instruments of financial support, especially in R\&D. R4 stated that the company's innovation projects do not fit into the requirements established by tax incentives, evidencing a limited knowledge about this instrument.

Company E5, founded in 1968, operates in the industrial automation with 550 employees in 2012. E5, multinational subsidiary, owns an ANPEI Stamp and five patents at the National Institute of Industrial Property (INPI). 
E5 uses tax incentives and, occasionally, the repayable and non-repayable resources. The company had a project approved by FINEP Grant, which allowed the conclusion that it was not interesting for the company to undergo the bureaucratic slowness for the amount of benefit to be granted, and considered more feasible the tax incentive, whose mechanism has been used by the company since 2008. It means that, one year after the creation of the Law $n^{\circ}$ $11,196 / 2005$, the company implemented a computerized system that formatted all the features of a process with integrated tax bookkeeping data.

R5 stated as the main obstacles to the use of public instruments innovation support, factors such as excessive bureaucracy at the funding agencies; the high costs involved with the project drafting; and the legal uncertainty arising from guarantees and contractual risks required to use these instruments. On the other hand, R5 mentioned tax incentive as a relevant instrument, due to the benefits of its adoption, such as reducing risks and increasing competitiveness and profitability of the company.

According to R5, the company chose "to develop innovations with its own resources because the response time of the funding agency is incompatible with the required time and with the reality of competitive markets in which the company operates". E5 also uses resources from support programs of the Federal Government of the country where its headquarters is located, which encourages the branches in Brazilian. In the country-origin of the multinational, there are four different dates in the year for project submission, with a response time of two weeks, according to R5, "a much faster process and much more compatible with the market requirements".

A medium-sized company established in 1982, E6 operates in the healthcare product sector with about 400 employees. Since 1994, the company has been seeking resources from third parties to develop innovations steadily and, since 2000, 16 international patents have been registered at the European Patent Office [EPO].

E6 has already used the financial benefit of FINEP four times, but R6 reported some disadvantages, for example, the amounts released would not meet the total need of the project and the elaboration of projects for submission requires highly specialized personnel. According to R6, the easier access to the FINEP benefits may have generated disinterest for BNDES instruments. E6 is unaware of the BNDES lines, except for the BNDES card, which has already been used by the company to reduce the need for its own investments. Regarding the Law $n^{\circ} 11,196 / 2005$, the company did not want to use tax incentives, due to the difficulty for its adoption, excessive bureaucracy and legal uncertainty. 


\section{FINAL REMARKS}

The results on the use of instruments for innovation support aimed to present a brief description of the operationalization of the instruments to support innovation from FINEP, and not from BNDES, as the bank has less tradition in funding innovation (CGEE; ANPEI, 2009), as well as to show the modalities of support offered by FINEP and BNDES.

The main contrast observed between the modalities of support offered by FINEP and BNDES is related to the integration of instruments and public policies. In most examples of governmental programs to innovation in the Brazilian scenario, there is no strict integration with instruments of support offered by FINEP and BNDES, whether endogenous or exogenous to the institution that operates them. In Brazil, it is still not possible to promote articulation between public agencies for innovation technological. Even within an institutional agency, for example, FINEP, one does not observe an integrated use of instruments to stimulate technological development (CGEE; ANPEI, 2009).FINEP has been designed to meet the needs of small and medium-sized enterprises, as in the case of the enterprises surveyed in our study. Major enterprises surveyed in this study prefer to use mechanisms for innovation support offered by FINEP rather than from BNDES, given that BNDES has less experience in financing innovation projects.

In relation to the preliminary results of the use of instruments to encourage innovation in companies in Brazil, the interviews were conducted at companies intentionally selected in terms of their commitment to innovation, attested by their values and business practices. The chosen respondents have relevant functions in the area of $R \& D$ and are encouraged by the company to seek closer relations with the academic sector to strengthen actions for RD\&I projects. The innovative nature of the companies can be confirmed, as in the case of E4, E5 and E6, by the existence of a structure of their own R\&D, absorbing specialists, Masters and PhD's while holding, as in the case of E6, partnerships with universities and research institutes

In General, the results showed that the companies investigated have knowledge of public instruments for innovation support, but they are unaware of support instruments that are generally not made available to the company, due to the size or time of existence of the company.

The main external factors reported by the companies that hinder the use of the instruments are excessive bureaucracy that causes the slowness of the assessment and approval processes of projects; the high costs of innovation (equipment, interest rates); 
reliability in the receipt of resources; and the legal uncertainty. The internal factor that hinders the use of the instruments by enterprises is the lack of qualified personnel for the elaboration and submission of the project and the consequent need to hire consulting firms specialized in innovation management.

For the respondents, an effort should be made for a comprehensive and efficient dissemination of support instruments in order to encourage their adoption by companies, which, with greater access, can be more productive, competitive and generate wealth and benefits that will be reflected in the growth and development of the country.

The instruments for innovation support should be aligned with corporate strategies, that is, the funding agencies should better articulate and operationalize the instruments they offer in order to align to the operational and organizational needs and specifics strategies of enterprises. The perception is that there is no consistent institutional policy in the scientifictechnological area that meets the real technological interests of enterprises. It is necessary that successful models from other countries also be adopted in Brazil. That would favor including branches of national enterprises installed in other countries.

In order to reduce bureaucracy and speed up the innovative projects of Brazilian companies, the Federal Government plans to allocate about US\$ 6.02billion between 2013 and 2014 for companies through FINEP and BNDES. Therefore, it is crucial that Brazilian companies be aware of new opportunities, mainly, structuring themselves for the use of resources for technological innovation.

Finally, this work refers to a very small number of companies, whose responses cannot be considered as representative of innovative companies in the country. In this sense, it is hoped that this work serves as instigating material for further comprehensive studies aimed at understanding the use of instruments for innovation support in Brazil.

\section{CONTRIBUTIONS BY THE AUTHORS}

Claudia Brito Silva Cirani prepared text-based, made the consolidation of data and text revision.

Carlos Mamori Kono collected the data, drafted and revised the text.

Andre Moraes dos Santos collected the data, drafted and revised the text.

Adalberto Ramos Cassia collected data, drafted and revised the text. 


\section{REFERENCES}

ANPEI. Associação Nacional de Pesquisa e Desenvolvimento das Empresas Inovadoras.

Anpei integra conselho de administração da Embrapii. 2009. Disponível em:

$<$ http://www.anpei.org.br/imprensa/noticias/anpei-integra-conselho-de-administracao-daembrapii/>. Acesso em: 20 maio 2013.

ARBIX, G. Fórum inovar para competir. Nossa economia tem de ser mais inovadora. 2013. Disponível em: <http://economia.estadao.com.br/noticias/economia-geral,nossa-economiatem-de-ser-mais-inovadora-diz-glauco-arbix,155600,0.htm>.Acesso em: 15 jun. 2013.

AVELLAR, A. P. Políticas de inovação no Brasil: uma análise com base na PINTEC 2008. Economia \& Tecnologia, v. 23, n. 6, p. 139-149, 2010.

BARDIN, L. Análise de conteúdo. Lisboa: Edições 70, 2000.

BASTOS, V. D. 2000-2010: uma década de apoio federal à inovação no Brasil. Revista do BNDES, v. 37, p. 127-176, 2012.

BNDES. Banco Nacional de Desenvolvimento Econômico e Social. Disponível em: <www.bndes.gov.br>. Acesso em: 13 abril 2015.

BRASIL. Lei n. 10.973 de 03 de Dezembro de 2004. Lei de inovação tecnológica. Diário Oficial da União n. 232. Brasília, DF: Congresso Nacional, 03 dez. 2004.

Ministério da Ciência Tecnologia e Inovação. Relatório anual da utilização dos incentivos fiscais, ano-base 2009. Lei n. 11.196/05. Lei do Bem. República Federativa [do] Brasil. Brasília (DF): Senado Federal, 2005.

CASSIOLATO, J. E.; LASTRES, H. Mecanismos de apoio à inovação no Brasil: uma breve nota crítica. In: CONFERÊNCIA NACIONAL DE CIÊNCIA, TECNOLOGIA \& INOVAÇÃO, 4., 2010, Brasília (DF). Anais... Brasília: CGEE, 2010. Disponível em: $<$ http://cncti4.cgee.org.br/index.php/banco- de-documentos/cat_view/60-4o-conferencianacional-de-ctai-2010/137-notas- tecnicas-dos-palestrantes>. Acesso em: 22 set. 2015.

CGEE. Centro de Gestão e Estudos Estratégicos; ANPEI. Associação Nacional de Pesquisa e Desenvolvimento das Empresas Inovadoras. Os novos instrumentos de apoio à inovação: uma avaliação inicial. Brasília (DF): ANPEI, 2009. Disponível em: <http://www.cgee.org.br/publicacoes/nov_instr_inov.php>. Acesso em: 20 mar. 2015

CONTANDRIOPOULOS, A. P. et al. Saber preparar uma pesquisa: definição, estrutura e financiamento. 2. ed. São Paulo: Abrasco, 1997.

CVM. Comissão de Valores Mobiliários. Relatório da administração e comentário do desempenho: demonstrações financeiras padronizadas. Disponível em:

$<$ http://www.rad.cvm.gov.br/enetconsulta/frmGerenciaPaginaFRE.aspx?CodigoTipoInstituica o=1\&NumeroSequencialDocumento=24398>. Acesso em: 27 maio 2014.

CRESWELL, J. W. Five qualitative traditions of inquiry. In: CRESWELL, J. W. Qualitative inquiry and research design: choosing among five traditions. Thousand Oaks: Sage, 1998, p. 47-72. 
FAGERBERG, J. A technology gap approach to why growth rates differ. Research Policy, v. 16, p. 87-99, 1987.

FAGERBERG, J.; VERSPAGEN, B. Technology-gaps, innovation-diffusion and transformation: an evolutionary interpretation. Research Policy, v. 32, p. 1291-1304, 2002.

FERRAZ, J. C.; PAULA, G. M.; KUPFER, D. Política industrial. In: KUPFER, D. E HASENCLEVER, L. (Orgs.). Economia industrial. Rio de Janeiro: Campus, 2002. cap. 23.

FINEP. Financiadora de Estudos e Projetos. 2014. Disponível em: <www.FINEP.gov.br〉. Acesso em: 19 abr. 2014.

FLEURY, A.; FLEURY, M. T. L. Aprendizagem e inovação organizacional: as experiências de Japão, Coréia e Brasil. 2. ed. São Paulo: Editora Atlas, 1997. cap. 5.

IBGE. Instituto Brasileiro de Geografia e Estatística. Pesquisa de inovação tecnológica 2008. Rio de Janeiro: IBGE, 2010.

MARCONI, M. A.; LAKATOS, E. M. Técnicas de pesquisa. 5. ed. São Paulo: Atlas, 2002.

PEREIRA, J. M.; KRUGLIANSKAS, I. Gestão de inovação: a lei de inovação tecnológica como ferramenta de apoio às políticas industriais tecnológicas do Brasil. RAE-eletrônica, v. 4, n. 2, 2005.

REZENDE, F.; TAFNER, P. Brasil: o estado de uma nação. Brasília: IPEA, 2005.

SALERNO, M. S.; DAHAER, T. PITCE: balanços e perspectivas. Brasília: Associação Brasileira de Desenvolvimento Industrial, 2006.

SCHUMPETER, J. Uma investigação sobre lucro, capital, crédito, juro e o ciclo Econômico. São Paulo: Editora Nova Cultural, 1997. Coleção Os Economistas.

STAL, E. Inovação tecnológica, sistemas nacionais de inovação e estímulos governamentais à inovação. In: MOREIRA, D. A.; QUEIROZ, A. C. S. (Orgs.). Inovação organizacional e tecnológica. São Paulo: Thomson Learning, 2007.

STAL, E.; CAMPANARIO, M. A.; ANDREASSI, T. A inovação tecnológica nas empresas e sua gestão. In: SBRAGIA, R. (Org.). Inovação: como vencer esse desafio empresarial. São Paulo: CLIO Editora, 2006.

SUZIGAN, W.; FURTADO, J. Política industrial e desenvolvimento. Revista de Economia Política, v. 26, n. 2 (102), p. 163-185, 2006.

PORTER, M. E. A vantagem competitiva das nações. Rio de Janeiro, Campus, 1993.

POSNER, M. V. International trade and technical change. Oxford Economic Paper, v. 13, p. 323-341, 1961.

TIDD, J.; BESSANT, J.; PAVITT, K. Gestão da inovação. Porto Alegre: Bookman, 2008. 